\title{
GENRE FEATURES OF THE CHUVASH ART PUBLICISM
}

\section{Albina Myshkina ${ }^{1 \star}$, Galina Yakovleva ${ }^{2}$, Tatyana Emelyanova ${ }^{3}$, Elena Ignatyeva ${ }^{4}$, Olga Yakovleva ${ }^{5}$}

\author{
${ }^{1}$ Prof. Dr., I.N. Ulianov Chuvash State University, RUSSIA, alb-myshkina@mail.ru \\ ${ }^{2}$ Prof. Dr., I.N. Ulianov Chuvash State University, RUSSIA, yakovlevagalinagr@mail.ru \\ ${ }^{3}$ Assoc. Prof., I.N. Ulianov Chuvash State University, RUSSIA, tanya.emel1981@yandex.ru \\ ${ }^{4}$ Assoc. Prof., I.N. Ulianov Chuvash State University, RUSSIA, alenaign70@mail.ru \\ ${ }^{5}$ Ph.D. candidate, I.N. Ulianov Chuvash State University, RUSSIA, yak-ol-nik@yandex.ru \\ ${ }^{*}$ Corresponding Author
}

\begin{abstract}
The enormous importance of publicism thought in the modern world is generally recognized. However, her aesthetic usefulness is still being questioned. So in Russian philological science there is no clear division of the concepts of "artistic journalism", "publicism", "journalism". Therefore, publicism is very often viewed either as a branch of fiction, or as a branch of journalism. But not as an independent branch of creative activity.
\end{abstract}

The purpose of our research is to analyze fictional publicism as an established phenomenon of fiction, which today stands on a par with psychological, philosophical, detective works. Historical-genetic and comparativehistorical methods were used as research methods, which make it possible to identify the links between an individual work and the development of a certain literary trend within the framework of the literature of a particular people.

The article touches upon the issues of the origins and ways of formation of artistic and publicistic prose, genre content and the system of images of a journalistic story in Chuvash literature. So the process of open rapprochement of publicism and fiction in the Chuvash culture is outlined in the 1920s-1930s and becomes more noticeable from the second half of the 1950s.

Chuvash prose writers of the journalistic style mainly see in the person of their readers a certain contemporary in the third person, a kind of simpleton who supposedly needs a detailed explanation of the very essence of the topic being touched upon. Therefore, they very often, with numerous quotations from scientists, excerpts from the works of Chuvash and Russian classics, or oral folk art, not so much argue the reasoning of their heroes, the narrator, as they conduct a kind of scientific "educational program". As a result, they one-sidedly deepen into the depths of a particular problem, interpret in detail or intrusively impose their idea, which often interferes with the aesthetic perception of the work. And this flaw is to a certain extent characteristic of all writers of modern Chuvash art publicism. In this regard, the writer acts not as an artist, but as a publicist who proceeds too straightforwardly from the idea to the hero and thereby expands the illustrativeness of the work. This artistic imperfection is very clearly manifested in the works of V. Alenday, $\mathrm{N}$. Maksimov, L. Tallerov and, to a lesser extent, A. Emelyanov.

Both publicists, critics, and literary researchers are almost unanimous that publicism is characterized, first of all, by an original, especially topical thought, an understanding of the current phenomena of life. However, it should be noted that wealth, originality of thought are not contraindicated in any work, moreover, this is an essential feature of any scientific and artistic work. It's just that in fictional journalism, unlike other styles of literature, such a thought is presented as a special, "self-propelled" one. For example, the idea of "erosion of the human soul", the decline of morality and spiritual purity in the works of Chuvash artistic journalism are revealed through the erosion of the earth ("Kuzma Ovrazhny" by A. Emelyanov) and through historical circumstances ("Shepherds" by A. Emelyanov and "Arkhip is a grandson Arkhip "L. Tallerov). 
Publicistic literature is a "sharp" literature, therefore the author's energetic "message" cannot be turned to anywhere, it is directly and unequivocally addressed to the reader. The peculiarity of a work of artistic journalism is largely determined by both the specifics of the national language and literature, and the worldview of the writer. For him, in contrast to other styles of literature, subordination to historical time is more characteristic, since the problems of the current period of the life of society are important for artistic journalism. And thanks to this feature of the artistic and journalistic style, first in Russian literature, then in national literatures, there is a synthesis of the feature article with the genres of the novel and story.

Keywords: Publicism, fiction literature, artistic and journalistic style, image and problem of artistic publicism, genre of publicism, Chuvash literature.

\section{INTRODUCTION}

The study of the ways of development of the artistic and journalistic style shows that the journalistic tendency of literature is considered from the point of view of the topicality of the ideas being implemented. Meanwhile, the synthesis of the documentary and the fictional presupposes the development of new criteria for evaluating artistic publicism. Scientists pay insufficient attention to the peculiarities of the artistic and speech structure of publicistic works. Having an indisputable independent status in modern literature, artistic publicism today is already developing new possibilities for aesthetic knowledge of reality. Despite this obviousness, one has to admit the fact that the style, poetics and genre of artistic publicism are still poorly understood. True, in Russian literary criticism, a number of studies are revealed that touch upon general issues of the problem under discussion and of nonfictional literature proper, taking into account its artistry. Among them, the works of E. Zhurbina, M. Cherepakhov, V. Zdorovega, V. Uchenova, A. Anikina, I. Chernukhina, G. Pospelov, E. Prokhorov and others deserve special attention. Their works reveal two approaches to the study of publicism and feature article. At the same time, the term "feature article" is more often used to denote a lack of artistry in a work.

In the studies of Chuvash literary scholars (N.S. Pavlov, V.S. Ezenkin, and others), the characterization of the style is often based on purely external qualities of a journalistic story: the topicality of the problem, acute polemicism, and the socio-political significance of the idea. All this suggests that neither Russian nor Chuvash literary criticism has developed genuine criteria for analyzing publicism genres of prose. An essential point for the Chuvash artistic journalism is the special structure of the expression of thought in the Chuvash language. However, in the Chuvash literary criticism, this has been little studied. Therefore, most researchers do not consider the problem of journalistic knowledge of modernity in a comprehensive manner, in the system of the main artistic searches of the writer, in whose work publicism often determines the entire artistic fabric of a work. Recently, a number of literary scholars (G.I. Fedorov, A.F. Myshkina, T.N. Emelyanova) have drawn attention to the natural tendency of the artistic and journalistic style towards deep philosophicality. The first shoots of a philosophical-analytical approach to understanding reality are observed in the stories of the late 1980 s by V. Petrov, L. Tallerov, A. Emelyanov, V. Alenday. A new level of development of the artistic and journalistic style falls on the 1990s. And all this requires a revision of the main criteria for the analysis of a publicistic work.

\section{OPINIONS AND DISCUSSION}

\subsection{Problems of Publicistic Prose in Literary Criticism and Criticism}

The phenomenon of fictional journalism in literature has a long history. According to the researcher of Old Russian literature D. Likhachev, some features of the artistic and journalistic style in Russian literature can already be traced in the 16th century: in business writing (the form of documentary, fact), in stories and legends (the form of narration: an appeal to the forms of oral speech, to forms of dialogue, reasoning, polemics, broad argumentation), in church literature (allegory). In Chuvash literature, the components of artistic journalism have been manifested since the end of the 19th century, in the works of such writers as I. Tkhti, M. Akimov, Ign. Ivanov. Moreover, literary scholars and critics, examining the history of the origin and development of Chuvash fiction, unequivocally note the journalistic orientation of all works of this period.

Artistic publicistic as a literary phenomenon in both Russian and Chuvash literary criticism, although not equally, has a generally recognized independence. Being at the junction of literature and journalism, it represents their arbitrary synthesis, subject to the universal law of literature - artistical. All the complexity of the problem arises in the terminological ambiguity of the concepts of "artistic journalism" and "artistic 
journalistic style". And here the socio-political and historical moment in the research and statements of scientists on this matter becomes an important factor. There are no significant differences in the interpretation of the concept of "publicistic" among different studies, just as there is no consensus of opinion. As N.I. Glushkov, "the concept of 'publicistic' as a feature of the literary style should not be confused with the concept of it as a thematic feature. But they should not be opposed either. In artistic publicistic, they are inseparable: a publicistic theme is developed in publicistic or journalistic style" (Glushkov, 1979, s. 57).

Chuvash literary critic G.I. Fedorov, dwelling on the explanation of the term "publicistic", notes that the publicistic style has already shown itself well in oral folk art: both in prose genres and in poetry. Therefore, the question of the figurative system of publicistic should become one of the principal ones in the Chuvash literature. By the way, the term "artistic and journalistic style" in Chuvash criticism and literary criticism acquired its true meaning only in the early 1990s. The problem of studying artistic publicistic as an independent style was first raised by G.I. Fedorov (Fedorov, 1990), considering the question of the originality of the Chuvash prose hero. In terms of defining the possible boundaries of artistic journalism, his monograph "The Artistic World of Chuvash Prose of the 1950-1990s" (Fedorov, 1996) is very significant. Note that the issues of Chuvash art publicistic were studied by G.Ya. Khlebnikov, V.S. Ezenkin, N.P. Pavlov, Yu.M. Artemiev and others.

It should be noted that many of the researchers' work were mainly carried out in the plane of documentary and journalistic-newspaper journalism. Publicism is considered by them in terms of its journalistic and newspaper functioning. With this approach to the problem, illustrativeness and factography occupy a dominant position in the work of publicistic. Meanwhile, in a work of fiction, simple imagery, polemics of thought, emotionality and rhetoric are clearly not the main, not decisive role. The factor of artistry itself is important here. And therefore, when studying the artistic and journalistic style, one should proceed from this concept.

\subsection{The System of Images of the Chuvash Publicistic Story of the 1950-1990s}

An essential point in the structure of the genre of the Chuvash artistic and journalistic story is traditionally its essay tendency. This was facilitated primarily by the fact that during a certain period of the development of literature (in particular, in the 1930s and during the Patriotic War), the essay generally became the leading and operational, as well as one of the main genres of fictionpublicistic. And only since the 1950s, due to historical circumstances, the artistic and journalistic style began to be actively developed as one of the independent branches of Chuvash literature. This was facilitated by many Chuvash writers, such as $H$. Uyar, A. Artemiev, N. Ilbek and, to a greater extent, A. Emelyanov, L. Tallerov, V. Petrov, N. Martynov, and others. During this period, in particular, in the works of Uyar, such an interesting and peculiar phenomenon of literature is revealed, when "attention to detail, historical accuracy and documentaryness in a single alloy are combined with fiction and generalization" (Artemiev, 1979, s. 67). At the same time, the author's national outlook leaves a noticeable imprint on everything narrated.

Such attempts at artistic and philosophical assimilation of life are found both in the works of A. Emelyanov ("The Name", "The Dry Year"), and in the works of L. Tallerov ("To Live", "Horse Ridge") and V. Petrov ("Kugamai "(Grandmother), "Fire "), etc. In these works, the main character or one of the heroes is tested for perseverance and moral impeccability in a dramatic situation. Thus, he finds new landmarks in life. Publicistic works are often based on a certain dramatic situation, covering the most diverse aspects of the hero's life. And everything here (analyticism, psychologism, and lyricism) is coordinated and regulated only by the hero - his stylistic sphere, his emotional tonality. Such are the heroes Modest Mukhtankin ("Name") and Velikanov ("Dry Year") A. Emelyanova, Elyuk ("To Live") and Pavel ("Horse Ridge") L. Tallerova, Semyon ("Kugamai") and Boris Mikhailovich Ukhvarkin ("Fire") V. Petrov. For example, for the hero of the story "Fire" such an incident is a fire set up by his own son.

In artistic journalism, not the idea, but the images are in the background, that is, it is not the image that gives rise to this or that thought, but the thought, the idea - of this or that hero, who, thanks to this very thought lying on the surface, acts this way and not otherwise, creates a certain a situation or a whole series of incidents. As a result, the pictorial beginning of such a work is inseparable from the analysis, the assessment is expressed directly and unambiguously. Therefore, the narrative here is not objectified, it usually unfolds in the form of subjective author's reflections, addressed directly to the reader and designed to conquer "both the brain and the soul". The specificity of the author's position leaves an imprint on the methods of creating character, the intonation of the narrative. For example, in the story "The Wind is Blowing" by V. Alenday and "The Name" by A. Emelyanov, a similar idea - an anti-alcohol campaign, which is only an accompanying main one - is expressed through the secondary characters Pukan Purise and Boris Perepelkin. However, A. Yemelyanov's journalistic beginning is sharper and more frank, the writer does not bypass, does not try to 
bypass the "sharp corners" of the problem being touched upon. In addition, the presence of a "documentary" author in publicistic entails the establishment of a special relationship between the writer and the reader. The epilogue is especially important for artistic publicistic directly related to modernity. The writer-publicist seeks to give the reader some results, conclusions that leave no doubt. And nevertheless, in a publicistic work, the author's subjectivity often fades into the background, giving way to the narrator and, which is very important for the fictionalistic publicistic style, the reader, who enter into polemics in the course of the development of the plot.

The presence of the narrator is deeply significant in artistic publicistic works. This is a very specific form of artistic reproduction of a person. The narrator is a mediator between the depicted and the reader, often acting as a witness and interpreter of the shown persons and events. The special role of the narrator in the work of the artistic and journalistic style leaves its mark both on his system of images and on the entire poetics of the genre. In a fictional journalistic story, he not only leads the story, but also is a kind of connecting link between the reader and the writer. However, the distance between author and narrator is enormous. "The author not only sees and knows everything that each hero sees and knows individually and all heroes together, but also more than them, and he sees and knows something that is fundamentally inaccessible to them, and in this always definite and stable excess of vision and the author's knowledge in relation to each hero, and there are all moments of completion of the whole - both heroes and the joint event of their life, that is, the whole work" (Bakhtin, 1979, s. 14). The image of the narrator in a work of fiction is not a direct identification, a reflection of the writer himself, because in each specific story he acts as the bearer of only a certain position of the creator, his views on the problem and the main idea. For example, in the stories "Shepherds" and "The Name" two positions are traced, two not contradictory, but complementary views of $A$. Yemelyanov on the political situation in the country, directly related to the main idea of these works. That is why the position of the narrator in them is optimally distinct and unambiguous.

The system of images of a fictional publicistic work primarily rests on the originality of the methods of creating a publicistic hero. For comparison, in pure publicistic, the publicist, in contrast to both the writer in fiction and the writer-publicist in artistic publicistic, mainly uses illustrative and photographic images. As a result, in such a work, the principle of conjecturing the primary reality begins to work by modifying readymade conflicts and plots in the structure of the genre. This approach to the problem of the hero is in no way applicable in fiction, where everything is subject to the laws of artistic reality and the principle of fiction. However, negative examples of speculation, taken directly from the facts of life, are found in fiction.

The choice of this or that theme in some way has its effect on the entire system of artistic images of the work. Naturally, such an impact is highly arbitrary, although not groundless. For example, production prose, in contrast to works about a village or any other, of course, creates a type of hero or heroes that is characteristic first of all for itself.

In the same way, artistic publicistic generates its own types of heroes, peculiar only to it. For example, in the system of images of the modern Chuvash artistic and publicistic style, first, the hero or heroes actively participating in the development of the plot are most clearly manifested. Secondly, the main character, who very often acts as a narrator. Thirdly, an episodic image that appears only in specific episodes, to a greater extent to confirm or, on the contrary, to refute a certain thought or even the entire main idea of the work. Fourthly, the image-symbol, the image-idea, traced through the entire work and most often veiled in subtext. Therefore, depending on the skill of the artist and the tasks he is solving, in each specific journalistic story a particular type of hero takes on a special role. On the other hand, it is the intensity of the publicistic type of the hero that contributes to the deepening of the idea, problematics and journalism of the entire work of art. Nevertheless, in some stories of the writers-publicists of the 1950-1990s, unfortunately, there is also a onesided strengthening, a clear preference for the problematics of the work to the detriment of its artistry. The cornerstone of such a work is a social conflict copied directly from current reality. In the Chuvash art publicistic, these qualities are most characteristic of V. Alenday's stories. Thus, responding to the social transformations in the society of the 1980s, the writer creates the stories "The Wind is Blowing" and "The Yellow Scarf with Golden Fringes", where he recreates the process of organizing and working of the family and team contract in detail.

A completely different, diametrically opposite approach to creating a hero of a publicistic work is outlined in the work of A. Emelyanov. The characteristic qualities of this artist's style are clearly manifested already in his first stories and novellas. However, during this period of his creative path, due to the then socio-political circumstances in the country, the writer chose the moral, spiritual side of the life of an individual and the whole society as the main idea, the core of his works. He does not in any way touch upon the issues of the socio-political system, which is very typical of the more mature Yemelyanov. For example, such are all his 
stories and novels included in the book "Not for the sake of glory", united by a common problem - the problem of spiritual and moral impoverishment of modern society, which is shown through specific human vices - greed, vanity, etc. Although such an approach to the problem morality in the work of Emelyanov is not the main one.

The Chuvash art and journalistic story received its full genre design in the literature of the 1950-1990s. So, the figurative system of a publicistic work of this period is characterized by a special place in it of the heronarrator, who plays the leading role of introducing a publicistic narrative line. These features of narrative speech also leave their mark on the storyline of a journalistic story, which is always straightforward and full of out-of-plot elements (descriptions, various digressions, arguments of the heroes).

\subsection{Genre Originality of a Journalistic Story and the Writer's Artistic World}

Any work of fiction (meaning, first of all, epic genres) is a kind of inner-spherical existence, a closed being, embedded in the consciousness of the writer. Naturally, the writer has his own ways of revealing the topic, his own thinking. For example, for Chuvash writers, including writers-publicists of the 1950-1970s, the most preferred and often touched upon topic is the problem of the modern village in its versatile coverage: both economic, and moral and human. Such are the works of V. Alenday "The Wind is Blowing, the Blowing", L. Tallerov "The River Flows", A. Emelyanov " Kuzma Ovrazhny ", "Spill of the Civil", "A Dry Year" and others.

And only since the mid-1980s those works of Chuvash artistic journalism appear, where a more politicized theme already prevails - the totalitarian system of the Soviet period of the country's development and the historical processes of today. Among such works, the most notable are the stories of A. Emelyanov "The Name", "Shepherds" (revised version) and L. Tallerov "Arkhip - Arkhip's grandson", N. Maksimov "Place in Life" and others.

The inner world of any work of art, including artistic publicistic, does not exist by itself and not for itself. It is not autonomous. This world depends on reality, "reflects" the world of reality, but the transformation of this world, which allows a work of art, has a holistic and purposeful character. The transformation of reality is primarily associated with the idea of the work and with the tasks that the artist sets for himself. Thus, the world of a work of art becomes the result of both correct display and active transformation of reality. It is this kind of unity of idea, plot and figurative system in relation to reality that is observed in L. Tallerov's story "To Live".

In a fictional publicistic work, descriptions can be distinguished that are closely related to the face (portraiture), with the place (scenic), with the conditions (situational) in which the action takes place. In addition, descriptions can be portrait, landscape, event. Thus, a landscape description depicts the atmosphere of the action. It either coincides with the inner world of the hero, or is discordant with him, is given by contrast. Examples of such a description can be found in A. Yemelyanov's novellas "Black mushrooms", "Kuzma Ovrazhny" and, especially clearly, in L. Tallerov's story "To Live". Naturally, the description has its purpose in fiction publicistic. Nevertheless, the best examples of artistic journalistic style show that the true publicistic in it is supported by another method of storytelling - reasoning. It is the reasoning that contributes to the deepening of the polemical confrontation and the development of the plot and heroes of the journalistic story. Reasoning in artistic publicistic aims to clarify some concept, develop, prove or refute some idea.

Modern literature does not accept a ready-made plot for a certain genre, style or direction, although its general features in a certain style are still outlined. So, works of fictional journalism are characterized by the maximum approximation of the plot to real life, with the aim of gaining the reader's trust and convincing him of the authenticity of the ideas put forward, and each writer has his own methods of convincing the reliability and documentality.

The writer A. Emelyanov also has his own individual approach to the plot. Who is in whose service: a person with power among the people, or the whole people with some leader? It is this idea that the writer develops in the plot of the story "Thirteen Months a Year". Note that the topic "man and power" is not new for the writer. He also raises this problem in the story "Kuzma Ovrazhny", but here it is not as widespread as in the story "Thirteen Months a Year." The writer-publicist leads the solution of the problems of man and power simultaneously from different positions: economic, moral, civil and state.

Reality, reflected in a publicistic work, in some cases reproduces reality quite accurately, in others it appears deformed, in a "strange", conventional form, with a shift in space-time parameters. That is why, for works of artistic journalism, the problem of interpreting spatio-temporal relations in it is very important. Time itself becomes here the subject of image and study. It is a means of expressing the ideological and content 
essence of a work and is transformed in comparison with historical time in the author's subjective embodiment. And it is comprehended, so to speak, in the absolute, as a philosophical concept, referring to the number of eternal themes in literature and art. Finally, time "materializes" in human destinies, in people's way of life, in their views, tastes, prejudices, and customs. Although in the work of different writers such an image of time is manifested in different ways: if, for example, the work of A. Emelyanov, L. Tallerov, and partly N. Maksimov is characterized by taking into account the time factor, then for V. Alenday it is not necessary at all.

His approach to understanding the temporal-spatial relations of a work is outlined in the work of L. Tallerov, whose name became known to a wide circle of readers long before the appearance of his first stories. It was at the beginning of his career (in the 1960s-1970s) that he declared himself as an established master of the essay genre. And this is quite understandable: the essay is the very genre of journalism, where the writerpublicist tries out the pen of the artistic and journalistic style. Probably, the same circumstance explains the writer's striving for a specific "small" time and space. In the work of L. Tallerov, this is not the only form of expression of an artistic idea. For example, one can speak very evasively about the journalistic nature of his first story "The River Flows". Despite the topicality of the problems discussed, the writer avoids sharp publicistic polemics, both between the heroes of the work and between the reader and the writer. Therefore, the originality of the artistic journalistic style of this writer should be discussed only in relation to some of his stories.

Publicism is unthinkable without analysis, argumentation and generalizations. Therefore, in fictional journalism, the writer, in order to convince the reader of the truthfulness and reliability of what is being told, introduces into the course of the narration numerous statements of famous figures of science, culture and social life, fragments and images of works of classical literature and folklore ("Name" by A. Emelyanov), uses the "weapon" of satire, in particular, hyperbole ("To live" by L. Tallerov), allegory ("A Place in Life" by N. Maksimov). The position of the writer-publicist, his lyric-civic "I" is that "magic crystal", passing through which the most prosaic, dry facts and data come to life, that angle of view that makes the reader not only empathize, but also reflect. Therefore, the way of expressing the writer's position in artistic journalism changes, comes in line with the subject and purpose of the work.

\section{CONCLUSION}

Being at the junction of literature and journalism, artistic publicistic is a kind of system of imaginative exploration of the world. A feature of its originality is that publicistic is directly dependent on the current time, the requests of the era. As a result, its functioning and significance especially increase in certain historical epochs. Such a period for the Chuvash art publicistic was the 1980s and especially the 1960s. This was facilitated by the political situation in the country (Khrushchev's "thaw" in the 1960s and perestroika in the 1980s) and the general development of the spiritual culture of society.

This development of the publicistic style in Chuvash literature allows us to say that it was the dominance of censorship, the inability to speak openly about the pressing problems of the current time that contributed to the strengthening of the artistry of the journalistic story, in particular, the strengthening of various forms of allegory (allegory, parable, etc.) and subtext in the system genre. This is also related to the fact that in the second half of the 1980s there was an intensive development of artistic publicistic of the political direction. And in the 1990s (that is, in the era of universal publicity), artistic publicistic changed, becoming more and more philosophical.

\section{REFERENCE LIST}

Artemiev, Yu.M. (1979). Problems and characters in the works of modern Chuvash prose // Problems of the creative method in Chuvash literature. Cheboksary: Chuvash Book Publishing House. S. 64 - 78.

Bakhtin, M.M. (1979). Aesthetics of verbal creativity. Moscow: Art. 420 s.

Glushkov, N.I. (1979). Essay prose. Rostov-on-Don: Rostov University Press. 148 s.

Emelyanova, T.N. (2019). Features of the original hero in the artistic publicistic works of A. Emelyanov // Ashmarin readings. Collection. Cheboksary: Chuvash State University. S. 108-110.

Myshkina, A.F. (2005). Chuvash art-philosophical and art-publicistic prose of the second half of the XX 
century: monograph. Cheboksary: Chuvash State University. 240 s.

Myshkina, A.F., Yadranskaya, I.V. (2021). Children of the era or the slave of their time (On the system of images and the image of the era in literature) // Development of education. T. 4. No. 2. S. 10-19.

Pavlov, N.S. (1964). M.F. Akimov - the founder of the Chuvash art journalism // "Uchenye zapiski" ChNII. Issue XXVII. Cheboksary: Chuvashgosizdat. S. 210 - 218.

Fedorov, G.I. (1990). The originality of the hero in Chuvash prose and other related issues // Modern Chuvash literature: Questions of artistic skill. Cheboksary: Chuvash Book Publishing House. S. 118143.

Fedorov, G.I. (1996). The artistic world of Chuvash prose 1950-1990s: monograph. Cheboksary: Chuvash Book Publishing House. 340 s. 